\title{
ASSESSING PERFORMANCE OF SMALL-SCALE PUMPED IRRIGATION SYSTEMS IN SUB-SAHARAN AFRICA: EVIDENCE FROM A SYSTEMATIC REVIEW ${ }^{\dagger}$
}

\author{
JEAN KAMWAMBA-MTETHIWA ${ }^{1,2 *}$, KEITH WEATHERHEAD ${ }^{2}$ AND JERRY KNOX \\ ${ }^{I}$ Natural Resources College, Lilongwe, Malawi \\ ${ }^{2}$ School of Energy, Environment and Agrifood, Cranfield University, Bedford, United Kingdom
}

\begin{abstract}
Small-scale irrigation (SSI) has significant potential to increase crop productivity in Sub Saharan Africa (SSA). Pumped irrigation systems are one of the technologies increasingly being used by smallholder farmers. The aim of this study was to systematically review evidence on the performance of SSI pumped systems, including motorized, treadle, rope and washer, solar and wind pumps. The study revealed a lack of standardization and use of a wide range of indicators to assess performance. Most evidence related to motorized pumps, these studies confirmed mixed levels of performance; studies relating to other types of pumped system mostly reported a positive impact, although the method of assessment used was critical. Studies reporting positive impacts tended to be those that used socio-economic based factors such as yield and profitability, whereas studies reporting mixed performance tended to be those that relied more on technically based indicators such as pumping and irrigation system efficiency. The analysis highlights the sensitivity of interpreting findings from different studies, and how caution should be exercised when comparing performance within and between different types of irrigation system. The implications for supporting policy development and identifying future research gaps are discussed.
\end{abstract}

KEY WORDS: small pumps; impact; technology; agriculture; performance factors

\footnotetext{
$\dagger$ Evaluation de la performance des petits pompe systèmes d'irrigation dans Afique Subsaharienne: preuve d'un examen systématique

* Correspondence to: Jean Kamwamba-Mtethiwa, Natural Resources College, P.O. Box 143, Lilongwe, Malawi.E-mail: j.t.mtethiwa@cranfield.ac.uk or jmtethiwa@gmail.com
} 


\section{RÉSUMÉ}

L'irrigation à la parcelle (SIP) a un grand potentiel pour améliorer les rendements agricoles de l'Afrique subsaharienne (ASS). La technologie la plus utilisée par les petits agriculteurs est celle des systèmes d'irrigation sous pressions. L'objectif de cette étude est d'effectuer une recherche systématique sur la performance des systèmes d'irrigation à la parcelle fonctionnant avec des pompes alimentées par des moteurs, pédales, cordes et rondelles, énergie solaire et éoliennes. L'étude a révélé un manque de norme de sécurité afin de vérifier les systèmes malgré le nombre conséquent d'indicateurs de performance utilisés. La plupart des études menées jusqu'à présent se sont focalisées sur les pompes à moteurs et ont démontré différents niveaux de performance; les études sur les autres types de systèmes ont largement signalés un effet positif de la SIP, même si la méthode d'évaluation utilisée est critique. Les études rapportant des résultats variables ont tendance à s'appuyer principalement sur l'évaluation des facteurs techniques utilisant des indicateurs tels que l'efficacité des systèmes de pompage et d'irrigation. L'analyse met en lumière la difficulté d'interprétation des résultats entre différents types de système d'irrigation. Leurs performances doivent être comparées et interprétés avec précautions.

MOTS CLÉS: pompes de taille réduite; l'impact; la technologie; l'agriculture; les facteurs de performance.

\section{INTRODUCTION}

Enhancing agricultural productivity remains a key strategy for poverty alleviation in most low income countries, where the majority of rural livelihoods depend on agriculture (Hussain and Hanjra, 2004). Sub-Saharan Africa (SSA) requires a rapid growth in agriculture to meet Millennium Development Goals and other targets for poverty alleviation and food security (Inocencio et al., 2007). There are thus increasing efforts to expand irrigation development. According to You et al. (2011) Africa has potential for both large and small-scale irrigation development, but there are concerns regarding the performance of large-scale irrigation systems as they are perceived as being too expensive and bureaucratic (Adams, 1990).

Small-scale irrigation (SSI) is considered one of the options for increasing agricultural productivity and supporting development in SSA. It is characterized by the use of simple technologies to access water for irrigation. Burney and Naylor (2012) defined water access technology as any method of moving water from its source to where it was previously unavailable. 
This includes all types of pump, from human powered, rope and treadle pumps to liquid fuel engine driven systems and solar powered pumps as well as gravity/river diversion methods. In SSA, a wide variety of such technologies have been introduced for SSI development since the 1990s. Gravity technology typically involves diverting water flows using open channels without pumping. Motorized systems include engine driven pumps, while treadle and rope and washer pumps are manual and wind and solar use renewable energy (Table I). Previously, most rural farmers in SSA have relied on traditional methods on small plots of land using for example, shadoof, buckets, watering cans, calabashes or blocking streams (Baba, 1993).

Table I. Key attributes of SSI water access technologies in Sub-Saharan Africa

\begin{tabular}{|c|c|c|c|c|c|c|}
\hline Attribute & $\begin{array}{c}\text { River } \\
\text { diversion }\end{array}$ & $\begin{array}{l}\text { Treadle } \\
\text { Pump }\end{array}$ & $\begin{array}{l}\text { Motorized } \\
\text { pump }\end{array}$ & $\begin{array}{l}\text { Solar/Wind } \\
\text { Pump }\end{array}$ & $\begin{array}{c}\text { Rope and } \\
\text { washer } \\
\text { pump }\end{array}$ & $\begin{array}{l}\text { Traditional } \\
\text { Methods }\end{array}$ \\
\hline Power source & Gravity & Human & Fossil fuel & Renewable & Human & Human \\
\hline $\begin{array}{l}\text { Type of } \\
\text { lift/pump }\end{array}$ & Gravity & Piston pump & $\begin{array}{l}\text { Centrifugal } \\
\text { pump }\end{array}$ & $\begin{array}{l}\text { Centrifugal } \\
\text { Pump }\end{array}$ & $\begin{array}{l}\text { Rope and } \\
\text { washer }\end{array}$ & $\begin{array}{c}\text { Bucket, } \\
\text { watering can or } \\
\text { calabash }\end{array}$ \\
\hline $\begin{array}{l}\text { Typical } \\
\text { discharge }\end{array}$ & $>10 \mathrm{l} / \mathrm{s}$ & Up to $2 \mathrm{l} / \mathrm{s}$ & $>21 / \mathrm{s}$ & $>21 / \mathrm{s}$ & Up to $1 \mathrm{l} / \mathrm{s}$ & $<11 / \mathrm{s}$ \\
\hline Water sources & $\begin{array}{l}\text { Surface } \\
\text { water }\end{array}$ & $\begin{array}{l}\text { Surface and } \\
\text { groundwater }\end{array}$ & $\begin{array}{l}\text { Surface and } \\
\text { groundwater }\end{array}$ & $\begin{array}{l}\text { Surface and } \\
\text { groundwater }\end{array}$ & $\begin{array}{l}\text { Surface and } \\
\text { groundwater }\end{array}$ & $\begin{array}{l}\text { Surface and } \\
\text { groundwater }\end{array}$ \\
\hline Initial cost & Low & $\begin{array}{l}\text { Moderate } \\
(\$ 20-\$ 100)\end{array}$ & $\begin{array}{c}\text { High } \\
(\$ 300-1500)\end{array}$ & $\begin{array}{l}\text { Very high } \\
(\$ 3,000- \\
10,000)\end{array}$ & Low & Very low \\
\hline $\mathrm{O} \& \mathrm{M}$ costs & Low & Moderate & High & High & Low & Very low \\
\hline $\begin{array}{l}\text { Typical irrigated } \\
\text { area (ha) }\end{array}$ & $>10$ ha & $<0.3$ ha & $>10$ ha & $>10$ ha & $<0.2$ ha & $<0.1$ ha \\
\hline
\end{tabular}

Gravity irrigation systems are usually the simplest and cheapest. However, their use is limited to specific topographical and hydrological conditions such that not all smallholder farmers can adopt such technology. SSI pumped systems are therefore a suitable alternative, and their use has substantially increased in SSA. Whilst there has been increased interest in pumped (manual and engine driven) systems, studies reporting on their performance and success have been mixed. Some claim they have had positive impacts on development (Mangisoni, 2008; Adeoti, 2008; Namara et al., 2010; Kamwamba-Mtethiwa et al., 2012) whilst others argue that they are too expensive and do not make any significant impact on smallholder farmers (Adams, 1990; Ashah 
et al., 2002; Inocencio et al., 2007; Chidanti-Malunga, 2009).

The term 'performance' has several meanings. In general terms it means the accomplishment of a given task measured against pre-set known standards of accuracy, completeness, cost and speed. Bos et al. (2005) described performance assessment as the comparison of the measured value of a parameter against a target or intended value. Irrigation system performance assessment is described as a systematic observation, documentation and interpretation of activities related to irrigated-agriculture with an objective of continuous improvement (Bos et al., 2005). Performance assessment indicators can be categorized into five broad domains including: (i) water delivery and utilization; (ii) agricultural production; (iii) agricultural economics; (iv) socio-economic; (v) environmental. It is recommended that all performance indicators are used to achieve an efficient, productive and effective irrigation system at all levels; however, the choice of which indicators to use in the assessment depends on researchers' interests. We argue here that evidence on performance of SSI pumped systems can only be obtained if the key drivers are identified and their measurement standardised. Although studies (Kimmage and Adams, 1990; Namara et al., 2010; Fujiie et al., 2011; Daccache et al., 2012) have attempted to review the performance of irrigation development in SSA, no systematic review (SR) has been undertaken on small-scale pumped irrigation development. We contribute to addressing this gap in knowledge by applying an SR approach to synthesize published science and grey evidence to identify the key factors affecting performance of SSI pumped systems and use the evidence to inform policies promoting SSI pumped system in SSA.

A number of recent studies have adopted the SR approach to gather evidence. For example, Knox et al. $(2012 ; 2013)$ assessed the impacts of climate change on yield of eight major crops in Africa and South Asia, and on the infrastructural impacts on agricultural development including irrigation, respectively. That latter study reported that about a third of evidence on irrigation development impacts on agricultural productivity were positive. The authors used measures such as income and poverty reduction. Fernandez et al. (2011) used a SR methodology to summarize knowledge relating to the usability evaluation methods (UEMs) to evaluate web applications over 14 years. That study was able to identify research gaps which subsequently provided researchers with a framework for new research. 


\section{METHODOLOGY}

This study used a robust SR methodology to synthesize evidence from published and grey literature. The main advantage of the SR approach is that it helps to realise the potential of data to inform whilst minimizing bias and uncertainty. It differs from conventional literature reviews in that it is a rigorous critical appraisal that draws on all relevant evidence with reference to a defined research question. The study followed the SR guidelines developed by the Collaboration for Environmental Evidence (CEE) and Centre for Evidence Based Conservation (CEBC) (2010). This included drafting a protocol to define the methodology followed by systematic literature searches and selection based on a set of 'inclusion criteria'. Relevant literature was screened in two stages; initial filtering was undertaken based on the title; a second filter was then based on the abstract. Full texts were only reviewed for those articles, reports and papers that passed all inclusion criteria. These inclusion criteria included specifying all relevant subjects, types of interventions, expected comparators, methods and outcomes. This involved (i) identifying potential 'effect modifiers' (other variables that might influence the outcomes) in the studies, (ii) specifying the data extraction techniques used to obtain qualitative and quantitative data, (iii) outlining quality assessment criteria for the studies which included validity of the methodologies and data analysis methods and (iv) identifying data interpretation and synthesis techniques depending on the amount and quality of data collected.

Based on CBEC guidelines (2010), we split our research question into elements considering: (i) population (agriculture narrowed down to beneficiaries- smallholders, rural communities, farmers, growers, households), (ii) intervention/exposure (small-scale pumped irrigation systems also known as irrigation technologies or water management including treadle, rope and washer, motorized (diesel and petrol), solar and wind pumps), (iii) comparator (changes relative to the intervention either before and after or with and without the interventions) and (iv) outcomes (change factors as a result of the intervention including changes in average yield, irrigated area, labour demand, energy need, farm income, food security). These elements are collectively referred to as PICO or PECO terms. Specific keywords were then selected, relevant scientific databases identified, search terms developed and then applied to each bibliographic database.

The search period was limited to studies published between 1990 and 2013 based on indications of increased interest SSI development in Africa (Baba, 1993; Fujiie et al., 2011). The search used trials in Scopus and finally two search strings (Irrigat* pump* AND Agricultur*) and (Irrigat* Pump* OR Water management OR Irrigat* technolog*" AND (Smallholder* OR Farmer* OR Grower* OR Rural Communit* OR Household*) were used to search all relevant 
scientific databases (Scopus, Science Direct, Web of Knowledge, Environmental Complete and Direct Access Journals), organization websites (e.g. World Bank, Food and Agriculture Organizations of the United Nations (FAO), Consultative Group on International Agricultural Research (CGIAR), African Development Bank (ADB), International Food Policy Research Institute (IFPRI), International Water Management Institute (IWMI) and International Fund for Agriculture Development (IFAD) and search engines (Google scholar and google.com). All references retrieved were exported into bibliographic software (Refworks) prior to assessment of relevance using the inclusion criteria. The bibliographies of identified sources were also searched. Only literature published in English was reviewed. Academic sources were sampled first, to avoid duplication from other databases. For search engines, a maximum 50 'hits' were reviewed using the same search strings.

This SR approach resulted in 1442 articles; based on the inclusion criteria these were screened by title (331) then abstract (101) and 35 papers finally selected for full review (Figure 1). It should be noted that 2 papers reported two pumped systems. Data extracted included year of publication, country where the study was conducted, size of irrigated area, types of pumped system, crops studied, performance indicators and final outcomes/impacts reported from the studies. The results were analysed using narrative synthesis categorised by performance factor. Attempts were also made to quantitatively analyze data based on crop yield information, however there were too few observations available.

\section{Clarification of terminologies and analytical methods}

Studies on irrigation performance assessment can be broadly divided into those providing methodological guidelines and those reporting irrigation performances (Yakubov, 2012). This review focused on studies that reported on actual performance. In the synthesis, the 35 selected papers were categorized according to the type of pumped systems studied (motorized, treadle, rope and washer and solar pumps). Data were further analysed by the reported impacts (positive, negative and mixed) and the performance assessment factors used. In order to identify key factors, it was apparent that the final outcomes of the studies be highlighted and linked to the key drivers used to assess performance. Studies were then classified as being positive if the intervention resulted in success, negative if the intervention failed and mixed if the outcomes included both elements of success and failure. Interpretation considered a factor as significant if performance assessment evidence resulted in mixed or failure outcome. 


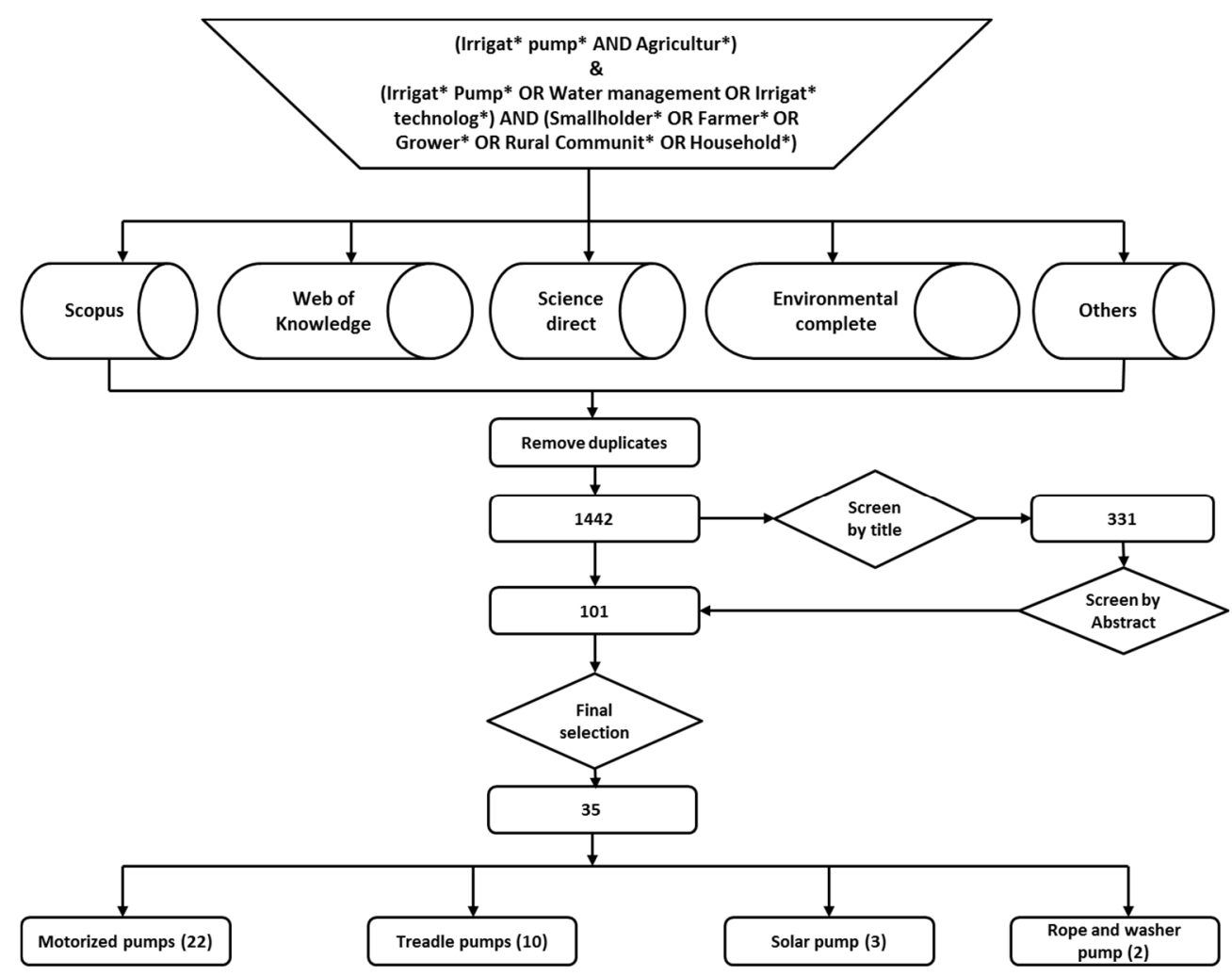

Figure 1 Schematic summary of the systematic review process

Given that the choice of performance factors used in studies largely depends on the researchers choice, this study aggregated the proposed five performance assessment domains by Bos et al. (2005) into social (SO), socio-economic (SE), agronomic (AG), technical (system/pump) efficiency (TS \&TP) and biophysical (BY). This was based on the reporting patterns in the selected studies. It was noted that studies were directly referring to these identified classes in their assessments although the specific performance indicators varied between the studies (Table II). There was also no clear separation in the studies between economic and financial factors and therefore the economic category in this classification included financial performance. Ideally these classes fit into the five broader domains as proposed by Bos et al. (2005) and Córcoles et al. (2010). 
Table II. Performance factors used in for screening the evidence.

\begin{tabular}{|c|c|}
\hline $\begin{array}{l}\text { Performance } \\
\text { factor }\end{array}$ & Parameters /indicators used \\
\hline Social & Management, technological, product organization, access and knowledge. \\
\hline $\begin{array}{l}\text { Socio- } \\
\text { economic (SE) }\end{array}$ & $\begin{array}{l}\text { Human capital (age, household size, education level) poverty levels, association } \\
\text { membership, number of extension visits, location, adoption, access to credit, } \\
\text { numbers of people emerging out of poverty, gender, threshold increasing levels } \\
\text { (with gender, household dependency ratio, distance to the market, owning land, } \\
\text { access to irrigation and association membership), food access, food utilization and } \\
\text { availability, household consumption }\end{array}$ \\
\hline $\begin{array}{l}\text { Economic } \\
(\mathrm{EC})\end{array}$ & $\begin{array}{l}\text { Water productivity, land productivity, returns to labour, return to land, return to } \\
\text { water, yield, net farm income under rain fed, net farm income under irrigated area, } \\
\text { rain-fed land holding size, irrigated production, net revenue, farm size, labour costs, } \\
\text { input costs, fixed/capital costs, gross margins, pump repairs costs, fuel costs, } \\
\text { marketing, income total per capita daily consumption, net farm income, household } \\
\text { expenditure, income from other sources, ability to pay back pump loan, set up costs, } \\
\text { labour, production cost, willingness to pay, operation and maintenance, asset } \\
\text { accumulation, financial capacity, energy costs, pump prices. }\end{array}$ \\
\hline $\begin{array}{l}\text { Agronomic } \\
\text { (AG) }\end{array}$ & $\begin{array}{l}\text { Crop water use efficiency, yield, plant height, fruit size, water consumption, water } \\
\text { use productivity. }\end{array}$ \\
\hline $\begin{array}{l}\text { Technical } \\
\text { system } \\
\text { efficiency } \\
\text { (ST) }\end{array}$ & $\begin{array}{l}\text { Irrigation efficiency, relative irrigation supply, water depth applied, irrigation } \\
\text { supply, irrigation frequency, labour efficiency, adequacy, reliability, flexibility, } \\
\text { equity, irrigation intensity, relative water supply, water source reliability, water } \\
\text { delivery capacity, main canal losses, seasonal irrigation requirement, uniformity } \\
\text { distribution, Christiansen coefficient, wetted diameter, water use efficiency. }\end{array}$ \\
\hline $\begin{array}{l}\text { Technical } \\
\text { pump } \\
\text { efficiency } \\
\text { (PT) }\end{array}$ & $\begin{array}{l}\text { Body Mass Index (BMI), pump power output, pump discharge rates, pump head } \\
\text { range, pump volumetric efficiency, pump mechanical efficiency, rope and washer } \\
\text { space, pump pulley rotational speed and pump hydraulic output, pump efficiency, } \\
\text { flow rate, hydraulic energy, daily volume, pump fuel consumption, labour } \\
\text { input/man-hours. }\end{array}$ \\
\hline $\begin{array}{l}\text { Biophysical } \\
\text { (BY) }\end{array}$ & $\begin{array}{l}\text { Straw/fodder production, stock carrying capacity and shrubland management } \\
\text { sustainability. }\end{array}$ \\
\hline
\end{tabular}




\section{RESULTS}

The review identified studies relating to thirteen countries of which eight (Mauritania, Ethiopia, Nigeria, Mali, Niger, Kenya, South Africa and Malawi) included motorized pumps, four (Malawi, Zimbabwe, Ghana and Kenya) treadle pumps, two (Benin and Ethiopia) solar pumps and one (Zimbabwe) rope and washer pumps. The types of pumped systems studied were regionally localised such that the majority that covered motorized and solar pumps were from West and East Africa whilst Southern African studies mostly related to treadle and rope and washer pumped irrigation systems. The majority of literature $(63 \%)$ focussed on motorized pumped systems, followed by treadle pumps (23\%), solar pumps $(9 \%)$ and rope and washer pumps $(6 \%)$. The review did not find any relevant studies on the use of wind pumps for irrigation. The majority of studies on motorized pumps related to rice followed by tomatoes, maize, onions and beans and sorghum. Very few studies reported the crop types under treadle pumps. No crops were reported by the studies on solar and rope and washer pumps. Different methodologies were reported to assess irrigation performance. The majority $(60 \%)$ used statistical methods based on quantitative data; however, due to 'effect modifiers' it was difficult to compare the quantitative findings. The review also attempted to analyse the impact of different pumped systems on crops; however, interpretation was limited by the very small sample size.

\section{Motorized pumped systems}

Table III summarises the evidence on motorized pumped irrigation, the comparators and performance factors used and reported outcomes. We then aggregated these results into studies that reported on positive, negative or mixed performance.

\section{Technical Efficiency, BY-Biophysical}

Socio-economic factors, followed by agronomic and economic factors; dominated studies that reported positive performance. Five of the eight studies reporting positive impacts used socioeconomic factors with measures in yield, profits, resource use, outputs, willingness to invest, household consumption, assets, crop revenues and informal insurance. The majority of these studies used yield and profit indicators. Three studies that assessed impact using agronomic and economic factors also used productivity (returns to land, water and fuel) and yield to measure impact. This reflects the importance of measuring agricultural productivity in understanding performance of small-scale pumped systems. While it may be difficult to compare the findings from such studies, the trends and patterns on use of common indicators in the assessment implied that the factors were significant indicators for positive outcomes of the motorized pumps.

Studies that reported a negative impact had used varied factors linked to productivity 
(returns to water, labour and energy, initial costs). However, effect modifiers within the studies made it difficult to separate out the direct impacts. Almost all had different comparators and were conducted at different scales.

Nearly half (41\%) of the evidence reported mixed impacts; only a few of these studies had used socio-economic factors for assessment. The use of technical (system and pump) efficiency factors was widespread. Positive impacts were mainly attributed to socio-economic assessments and negative impacts mainly related to technical assessments. This highlights the attributes that particular performance assessment factors can have on expected outcomes suggesting the significance of technical factors on performance.

\section{Treadle pumped systems}

Nearly a quarter (23\%) of evidence selected in the SR related to treadle pumps, possibly implying that these are the technologies that are the preferred choice among developing organizations, donors and researchers. Most studies were from Malawi reflecting the fact that they are being heavily promoted by the Government of Malawi (2010). The majority (70\%) of studies reported positive performance impact relating to food security, poverty reduction and crop revenue (Table IV). Most studies reporting positive impact used socio-economic factors. Those that reported a negative impact attributed poor performance to the pump labour demand. One study reported mixed performance based on both technical and socio-economic factors. These findings concur with the observations above on motorized pumps.

\section{Solar pumps}

There was very limited evidence found on the use of solar pump technology (Benin and Ethiopia only). All studies on solar pump systems were published relatively recently (Burney et al., 2010; Jeffries, 2010; Burney and Naylor, 2012), indicative of a recently introduced technology in the region. All these studies reported a positive impact; two-thirds used socio-economic factors for assessment; the remainder focussed on assessing the technical efficiency of the pumped system.

\section{Rope and washer pumps}

There were only two (Faulkner et al., 1990; Faulkner and Lambert, 1990) studies identified, both from Zimbabwe reporting a positive impact; No recent publications possibly suggest that this is now an abandoned technology. 
Table III. Selected studies for motorized pumped systems, comparators, performance indicators and outcome (impact)

\begin{tabular}{|c|c|c|c|c|c|c|c|c|c|c|c|c|}
\hline \multirow[t]{2}{*}{ No } & \multirow{2}{*}{$\begin{array}{l}\text { Country of } \\
\text { study }\end{array}$} & \multirow[t]{2}{*}{ Comparator } & \multicolumn{7}{|c|}{ Performance factor assessed $* *$} & \multirow[t]{2}{*}{ Outcome } & \multirow{2}{*}{$\begin{array}{l}\text { Indicator used to quantify } \\
\text { impact }\end{array}$} & \multirow[t]{2}{*}{ Source } \\
\hline & & & $\mathrm{SO}$ & SE & $\mathrm{EC}$ & $\mathrm{AG}$ & PT & ST & $\mathrm{BY}$ & & & \\
\hline 1 & Nigeria & Traditional & & $\checkmark$ & & & & & & Positive & Resource-use, yield \& profit & Baba (1993) \\
\hline 2 & Mali & Pumped irrigation & & $\checkmark$ & & & & & & Positive & $\begin{array}{l}\text { Household consumption, } \\
\text { assets \& informal insurance }\end{array}$ & Dillon (2011) \\
\hline 3 & Mauritania & $\begin{array}{l}\text { Pumped irrigation- } \\
\text { sorghum Vs rice }\end{array}$ & & & $\checkmark$ & $\checkmark$ & & & & Positive & Crop profitability & $\begin{array}{l}\text { García-Ponce } e t \\
\text { al. (2013) }\end{array}$ \\
\hline 4 & Nigeria & $\begin{array}{l}\text { Adoption with and } \\
\text { without rainfall risks }\end{array}$ & & $\checkmark$ & & & & & & Positive & Willingness to investment & $\begin{array}{c}\text { Takeshima \& } \\
\text { Yamauchi (2012) }\end{array}$ \\
\hline 5 & Niger & Traditional & & & $\checkmark$ & $\checkmark$ & & & & Positive & Profits & $\begin{array}{l}\text { Woltering et al. } \\
\qquad \text { (2011) }\end{array}$ \\
\hline 6 & Ethiopia & $\begin{array}{l}\text { Drip and furrow pumped } \\
\text { systems }\end{array}$ & & & & $\checkmark$ & & & & Positive & Crop yield & $\begin{array}{l}\text { Yohannes and } \\
\text { Tadesse (1998) }\end{array}$ \\
\hline 7 & Nigeria & Rain fed agriculture & & $\checkmark$ & & & & $\checkmark$ & & Positive & Outputs and tech efficiency & Adeoti (2006) \\
\hline 8 & Ethiopia & $\begin{array}{l}\text { socio-economic } \\
\text { performance }\end{array}$ & & $\checkmark$ & & & & & & Positive & Crop revenue & $\begin{array}{l}\text { Mengistu et al. } \\
\text { (2008) }\end{array}$ \\
\hline 9 & Malawi & $\begin{array}{l}\text { Different pump and } \\
\text { traditional irrigation }\end{array}$ & & $\checkmark$ & & $\checkmark$ & & & & Negative & $\begin{array}{l}\text { Water and fuel productivity, } \\
\text { labour, yield and revenue }\end{array}$ & $\begin{array}{c}\text { Kadyampakeni et } \\
\text { al. (2012) }\end{array}$ \\
\hline 10 & Mauritania & Traditional & & $\checkmark$ & & & & & & Negative & $\begin{array}{l}\text { Return to labour and inputs/ } \\
\text { workload }\end{array}$ & $\begin{array}{l}\text { Comas et al. } \\
\text { (2012) }\end{array}$ \\
\hline 11 & Mauritania & $\begin{array}{c}\text { Pumped systems-scheme } \\
\text { performance }\end{array}$ & & & $\checkmark$ & & & $\checkmark$ & & Negative & $\begin{array}{c}\text { Productivity of land, water } \\
\text { and fuel }\end{array}$ & $\begin{array}{c}\text { García-Bolaños et } \\
\text { al. (2011) }\end{array}$ \\
\hline
\end{tabular}




\begin{tabular}{|c|c|c|c|c|c|c|c|c|c|c|c|c|}
\hline 12 & Kenya & $\begin{array}{c}\text { Pumped system-pump } \\
\text { efficiency }\end{array}$ & & & & & $\checkmark$ & & & Negative & Pump efficiency & $\begin{array}{c}\text { Kang'au et al. } \\
\text { (2011) }\end{array}$ \\
\hline 13 & Nigeria & $\begin{array}{c}\text { Adoption with \& } \\
\text { without transaction costs }\end{array}$ & & $\checkmark$ & & & & & & Negative & Transaction costs, gender & $\begin{array}{c}\text { Takeshima et al. } \\
\text { (2010) }\end{array}$ \\
\hline 14 & Mauritania & Large scale & & & & & & $\checkmark$ & & Mixed & $\begin{array}{l}\text { Technical efficiency-Land } \\
\text { productivity and energy cost }\end{array}$ & $\begin{array}{l}\text { Borgia et al. } \\
\text { (2013) }\end{array}$ \\
\hline 16 & $\begin{array}{l}\text { South } \\
\text { Africa }\end{array}$ & $\begin{array}{l}\text { Economic productivity } \\
\text { of pumped systems }\end{array}$ & & & $\checkmark$ & & & & & Mixed & $\begin{array}{c}\text { Water value and } \\
\text { productivity }\end{array}$ & Yokwe (2009) \\
\hline 17 & Ethiopia & Large scale & $\checkmark$ & & & & & & & Mixed & Technological management & Awulachew (2010) \\
\hline 18 & Mauritania & $\begin{array}{l}\text { Other production } \\
\text { systems }\end{array}$ & & & $\checkmark$ & $\checkmark$ & & & $\checkmark$ & Mixed & $\begin{array}{l}\text { Irrigated area, crop diversity } \\
\text { and stock carrying capacity }\end{array}$ & $\begin{array}{c}\text { Connor et al. } \\
\text { (2008) }\end{array}$ \\
\hline 19 & Ethiopia & $\begin{array}{c}\text { Scheme efficiency of } \\
\text { pumped system }\end{array}$ & & & $\checkmark$ & & & $\checkmark$ & & Mixed & $\begin{array}{l}\text { Water \& land productivity, } \\
\text { rate of returns on investment }\end{array}$ & Hassen (2004) \\
\hline 20 & Mauritania & $\begin{array}{c}\text { Before and after } \\
\text { rehabilitation }\end{array}$ & & & & & & $\checkmark$ & & Mixed & $\begin{array}{c}\text { Reliability, flexibility and } \\
\text { pumping capacity }\end{array}$ & $\begin{array}{l}\text { Mateos et al. } \\
\text { (2010) }\end{array}$ \\
\hline 21 & Mali & $\begin{array}{l}\text { Social changes with } \\
\text { flood irrigation }\end{array}$ & $\checkmark$ & & & & & & & Mixed & $\begin{array}{l}\text { Organization capacity, water } \\
\text { access \& knowledge }\end{array}$ & $\begin{array}{c}\text { Ton and De Jong } \\
\text { (1991) }\end{array}$ \\
\hline 22 & Ethiopia & $\begin{array}{l}\text { Socio-economic } \\
\text { performance }\end{array}$ & & $\checkmark$ & & & & $\checkmark$ & & Mixed & $\begin{array}{c}\text { Income and water use } \\
\text { efficiency }\end{array}$ & $\begin{array}{c}\text { Van Halsema } e t \\
\text { al. (2011) }\end{array}$ \\
\hline & Total & & 2 & 9 & 6 & 5 & 2 & 6 & 1 & & & \\
\hline
\end{tabular}

**SE-Socio-economics, EC-Economic, AG-Agronomic, PT-Pump Technical Efficiency, ST Scheme 
Table IV. Summary evidence on treadle pump performance, by country and performance factor

\begin{tabular}{|c|c|c|c|c|c|c|c|c|c|}
\hline \multirow[t]{2}{*}{ No } & \multirow[t]{2}{*}{ Country of study } & \multirow[t]{2}{*}{ Comparator } & \multicolumn{4}{|c|}{ Performance factor } & \multirow[t]{2}{*}{ Outcome } & \multirow[t]{2}{*}{ Indicators used } & \multirow[t]{2}{*}{ Source } \\
\hline & & & $\mathrm{SE}$ & $\mathrm{EC}$ & $\mathrm{AG}$ & PT & & & \\
\hline 1 & Ghana & Non adopters & $\checkmark$ & & & & Positive & Adoption factors and poverty & Adeoti, (2008) \\
\hline 2 & Zimbabwe & $\begin{array}{l}\text { Different pump } \\
\text { types }\end{array}$ & & & & $\checkmark$ & Positive & Pump and drip designs & Chigerwe et al. (2004) \\
\hline 3 & Zimbabwe & $\begin{array}{l}\text { Different pump } \\
\text { design }\end{array}$ & & & & $\checkmark$ & Positive & Pump hydraulic output & Faulkner et al. (1990) \\
\hline 4 & Malawi & Furrow irrigation & & $\checkmark$ & $\checkmark$ & & Positive & $\begin{array}{c}\text { Labour, yield and drip } \\
\text { efficiency }\end{array}$ & Fandika et al. (2012) \\
\hline 5 & Malawi & Non adopters & $\checkmark$ & & & & Positive & $\begin{array}{c}\text { Poverty levels and household } \\
\text { income }\end{array}$ & Mangisoni, (2008) \\
\hline 6 & Kenya & Before and after & $\checkmark$ & & & & Positive & Income and loan repayment & Pandit et al. (2010) \\
\hline 7 & Malawi & Non adopters & $\checkmark$ & & & & Positive & $\begin{array}{l}\text { Net farm income, adoption, } \\
\text { household income, expenditure }\end{array}$ & $\begin{array}{c}\text { Kamwamba-Mtethiwa et } \\
\text { al. (2012) }\end{array}$ \\
\hline 8 & Malawi & Pump efficiency & & & & $\checkmark$ & Negative & Labour and pump discharge & $\begin{array}{l}\text { Joseph and Yamikani, } \\
\text { (2011) }\end{array}$ \\
\hline 9 & Malawi & Traditional & $\checkmark$ & & & & Negative & Labour, gross margins & Chidanti-Malunga, (2009) \\
\hline 10 & Malawi & $\begin{array}{l}\text { Motorized pump and } \\
\text { traditional }\end{array}$ & $\checkmark$ & & $\checkmark$ & & Mixed & $\begin{array}{l}\text { Labour, yield, crop revenues } \\
\text { and water productivity }\end{array}$ & $\begin{array}{l}\text { Kadyampakeni et al. } \\
\text { (2012) }\end{array}$ \\
\hline & Total & & 6 & 1 & 2 & 3 & & & \\
\hline
\end{tabular}

**SE-Socio-economics, EC-Economic, AG-Agronomic, PT- Pump Technical Efficiency 


\section{DISCUSSION}

The increased use of SSI pumped systems in SSA has been established on the grounds that larger scale irrigation schemes have often failed (Fujiie et al., 2011). It is believed that pumped systems are among the simple technologies that support smallholder farmers to access water from sources that may not be possible with gravity. Furthermore, it is assumed that the benefits from these pumped systems directly benefit smallholder farmers by increasing agricultural production and farmer incomes (Baba, 1993; Dillon, 2011). However, this study found that evidence relating to SSI pumped system performance is limited, lacks standards and is geographically focused within a particular region in SSA. This study proposes that a number of factors have contributed to these differences found in the literature.

Firstly, this SR has revealed that studies assessing performance of small-scale pumped systems are framed to serve the interests of those driving them. This was demonstrated by the biasness in the evidence on particular pumps that were also supported by the developing organizations. For example, we found that there were more studies relating to treadle pumps compared to motorized pumps especially in southern SSA; coincidentally, many developing organizations in this region are supporting the up-take of treadle pumps (Mangisoni, 2008). Similarly, it was found that the only evidence relating to rope and washer pumps (Faulkner et al., 1990; Faulkner and Lambert, 1990), were provided by the authors that participated in the pump design. On the other hand, studies involving the IWMI (e.g. Namara et al, 2013; 2014) have reported a rapid rise in the use of private small motorized pump but their evidence in the region is patchy. It is therefore argued that the current evidence on SSI pumps in the SSA is not entirely based on literature but rather the interest of the various actors involved. This is supported by Sumberg et al. (2012), who argued that most contemporary evidence in the literature exposes major epistemological and ontological divisions in relation to the value of different kinds of knowledge and the nature of the innovation since the focus is on performance of the technology. This might help to explain the reasons why some pumped systems are often positively assessed while others are not.

Second, there are no common approaches or standards adopted for assessing the factors that affect system performance. Socio-economic factors such as profits, assets accumulation, yield dominated the reporting of positive performance while most technically based assessments reported mixed or negative performance (Tables III and IV). While the positive socio-economic impact of the systems studied may be consistent with evidence from other SRs (Knox et al., 2013), it is important to recognize that socio-economic changes in smallholder communities could be a result of influences from numerous sources. Considering the household as a unit with a range of 
income sources, farmers' socio-economic changes cannot be entirely attributed to the contributions made by the pumped systems interventions. For example, evidence from the New Partnership for Africa's Development (NEPAD) (2003) revealed the goals for many developing organizations in SSA are geared towards the rural poor, thus on socio-economic changes. This could explain why socio-economic studies reported positive impact in their performance assessment. However, this study revealed that technical factors are also important in the success of SSI pumps. This supports previous studies (Adams, 1990; Njiraini and Guthiga, 2013; Borgia et al., 2013) that argued that most small irrigation systems in SSA are not technically effective. Similarly, in Kenya, Kulecho and Weatherhead (2006) suggested that the failure of drip irrigation systems was due to a lack of maintenance and unreliable water supply suggesting that abandonment of most irrigation technologies are likely due to their technical challenges. This has implications for the choice of factors for assessing pumped system performance.

Finally, there was a lack of differentiation between rapid and more detailed comprehensive assessments of small pumped systems. For example in Nigeria, Baba (1993) took three years to conduct a socio-economic assessment of the impact of pumped systems; in contrast, it took only three months to socio-economically assess schemes in Ethiopia (Mengistu et al., 2008). The outcomes from both these studies showed a positive impact regardless of differences in their duration of assessment. However, it is possible that other factors such as other previous income sources may have contributed to the positive impact on the evidence found in the short duration study. This demonstrates the potential risks associated with the evidence and likely inconsistencies in the outcomes.

The findings from this study have important implications for policies to promote the uptake of small capacity pumps. The limited evidence base means that current policies (e.g. NEPAD, 2003 ) in SSA are likely to be based on evidence that is not sufficiently robust. This supports recent studies (Matekele and Lema, 2012) that reported on performance assessment in smallholder irrigation to be rather ad hoc, fragmented and mainly conducted at the outset of projects to serve the interest of those that initiated the process. It is thus suggested that further targeted research should be undertaken to inform policy formulation. For the unclear standards, this study has argued that this was likely to be result of different methods and the lack of clear procedures to differentiate comprehensive and rapid performance assessment methods. Given the importance of understanding the technical and socio-economic factors, we propose that performance assessment standards that incorporate a set of key factors should be developed. This will enable directly comparable evidence on performance of SSI pumped systems to be gathered and more objectively compared. It is also suggested that clear guidelines associated with conducting either rapid or comprehensive performance assessments should be developed. Finally, the differences 
in policies in the SSA countries might help to explain some of the reasons why the evidence found was localized. It is suggested that an inventory of the SSI pumped systems should be developed. This will provide a baseline data for developing performance assessment standards that are specific to the pumped system.

Despite the limited evidence base collated from this SR, the study provides valuable insights on the gaps in the knowledge on SSI pumped systems in SSA. Furthermore, the review has used robust methods and processes to gather the evidence and thus the findings are a true reflection of the magnitude of evidence that is available in the SSA.

\section{Methodological limitations}

The main limitations in adopting a SR approach typically relates to selection bias, inaccuracy in data extraction and the presence of 'effect modifiers'. Selection bias refers to biases in identifying studies for the subsequent analysis; inaccuracy in data extraction refers to the possibility of extracting wrong or inaccurate evidence from the various bibliographic databases or other literature sources; 'effect modifiers' refers any variable that modify the impact of an intervention or exposure. The evidence identified in this SR differed in terms of its geographical coverage, the varying scales of analysis for example, household to village, and the approaches used for measuring performance impact. In addition, the studies varied widely in their approaches to assessing performance, from comparing pumped systems with rain-fed production, to traditional irrigation, to rehabilitated schemes, to different pumped systems. The time scale over which the studies were conducted was also an important factor; some studies assessed performance over relatively long periods (more than six years) whilst others were carried out over much shorter periods (single irrigation season). Different pump design, pump sizes and irrigation application methods might also have been important effect modifiers. For example, the high frequency or citing in the literature for a certain type of technology, does not necessarily equate to a high significance of the technology in terms of area, production or income. The SR outputs should therefore be interpreted with caution.

\section{CONCLUSIONS}

This study provides a valuable contribution to the international science literature by identifying the key factors that affect the performance of SSI pumped systems in SSA and the extent to which technical and socio-economic factors are used as metrics of performance. The study has highlighted the limited evidence on SSI pumped systems and that it is geographically biased 
(treadle pumps-southern SSA, motorized pumps-West and East SSA). Nevertheless, the evidence should be helpful in defining where strategic research is needed to improve methods and approaches for assessing performance. Our analysis suggests that current policies to support SSI pumped systems should embrace both technical and socio-economic issues in their development programmes and should adopt more standardized methods for assessment to allow comparison and replication.

\section{ACKNOWLEDGEMENT}

The lead author acknowledges the Commonwealth Scholarship Commission (CSC) for financial support. Dr Andre Daccache and Dr Kenneth Wiyo are thanked for their guidance in the implementation of the SR process. We also thank the anonymous reviewers for their constructive comments.

\section{REFERENCES}

Adams WM. 1990. How beautiful is small: Scale, control and success in Kenyan irrigation. World Development, vol. 18, no. 10, pp. 1309-1323.

Adeoti AI. 2008, Factors influencing irrigation technology adoption and its impact on household poverty in Ghana. Journal of Agriculture and Rural Development in the Tropics and Subtropics. vol. 109, no. 1, pp. 51-63.

Ashah T, Van Koppen B, Merrey D, De Lange M, Samad M. 2002. Institutional Alternatives in Small holder Irrigation: Lessons from international experience with irrigation Management Transfer. 60. International Water Management Institute, Corombo, SriLanka.

Baba KM. 1993. Irrigation development strategies in sub-Saharan Africa: A comparative study of traditional and modern irrigation systems in Bauchi State of Nigeria. Agriculture, Ecosystems \& Environment, vol. 45, no. 1-2, pp. 47-58. DOI: 10.1016/01678809(93)90058-W

Borgia C, García-Bolaños M, Li T, Gómez-Macpherson H, Comas J, Connor D, Mateos L. 2013. Benchmarking for performance assessment of small and large irrigation schemes along the Senegal Valley in Mauritania. Agricultural Water Management, vol. 121, no. 0, pp. 19-26.

Bos MG, Burton MA, Molden DJ. 2005. Irrigation and Drainage Performance Assessment, Practical Guidelines. CABI Publishing. 
Burney J, Woltering L, Burke M, Naylor R, Pasternak D. 2010. Solar-powered drip irrigation enhances food security in the Sudano-Sahel. Proceedings of the National Academy of Sciences of the United States of America, vol. 107, no. 5, pp. 1848-1853. DOI: 10.1073/pnas.0909678107

Burney JA, Naylor RL. 2012. Smallholder Irrigation as a Poverty Alleviation Tool in Sub-Saharan Africa. World Development, vol. 40, no. 1, pp. 110-123. DOI: 10.1016/j.worlddev.2011.05.007

Centre for Evidence-Based Conservation. 2010. Guidelines for Systematic Review in Environmental Management, 4.0: Environmental Evidence: www.environmentalevidence.org/Authors.htm.

Chidanti-Malunga JF. 2009. Wetland farming and Small scale informal irrigation in Malawi: The case of Shire Valley. PhD thesis: Cranfield University. United Kingdom

Córcoles JI, de Juan JA, Ortega JF, Tarjuelo JM, Moreno MA. 2010. Management evaluation of Water Users Associations using benchmarking techniques. Agricultural Water Management, vol. 98, no. 1, pp. 1-11.

Dillon A. 2011. The Effect of Irrigation on Poverty Reduction, Asset Accumulation, and Informal Insurance: Evidence from Northern Mali. World Development, Vol. 39 no. 12, pp. 21652175. DOI: 10.1016/j.worlddev.2011.04.006

Faulkner RD, Lambert RA, Ryan TF. 1990. Micro-Scale Irrigation Utilizing Human Powered Pumps. Zimbabwe Science News, vol. 24, no. 7-9, pp. 64-69.

Faulkner RD, Lambert RA 1990. Use of the rope-washer pump in micro-scale irrigation', Proceedings of the Institution of Civil Engineers (London). Part 1 - Design \& Construction, vol. 88 , pp. 81-90.

Fujiie H, Maruyama A, Fujiie M, Takagaki M, Merrey D, Kikuchi M. 2011. Why invest in minor projects in sub-Saharan Africa: An exploration of the scale economy and diseconomy of irrigation projects. Irrigation \& Drainage Systems, vol. 25, no. 1, pp. 39-60.DOI: 10.1016/j.gloplacha.2012.06.004

García-Bolaños M, Borgia C, Poblador N, Dia M, Seyid OMV, Mateos L. 2011. Performance assessment of small irrigation schemes along the Mauritanian banks of the Senegal River. Agricultural Water Management, vol. 98, no. 7, pp. 1141-1152. DOI: 10.1016/j.agwat.2011.02.008

García-Ponce E, Gómez-Macpherson H, Diallo O, Djibril M, Baba C, Porcel O, Mathieu B, Comas J, Mateos L, Connor DJ. 2013. Contribution of sorghum to productivity of smallholder irrigation schemes: On-farm research in the Senegal River Valley, Mauritania. Agricultural Systems, vol. 115, pp. 72-82. DOI: 10.1016/j.agsy.2012.09.009 
Government of Malawi. 2010. Annual reports and notes. Department of Irrigation, 1, MoAFS Lilongwe, Malawi.

Hussain I, Hanjra MA. 2004. Irrigation and poverty alleviation: Review of the empirical evidence. Irrigation and Drainage, vol. 53, no. 1, pp. 1-15.

Inocencio A, Kikuchi M, Tonosaki M, Muyama A, Merrey D, Sally H, de Jong I. 2007. Cost and Performance of Irrigation Projects: A comparison of Sub-Saharan Africa and other developing regions. 109, International Water Management Institute (IWMI), Corombo, Sri Lanka.

Jeffries N. 2010. Viability study of a new low-power solar thermal irrigation pump for smallholder farmers in low-income countries', Msc Thesis, University of East London. London, United Kingdom.

Kamwamba-Mtethiwa J, Namara R, De Fraiture C, Mangisoni J, Owusu E. 2012. Treadle pump irrigation in Malawi: Adoption, gender and benefits. Irrigation and Drainage, vol. 61, no 1, pp 583-595. DOI: 10.1002/ird.1665.

Kimmage K, Adams WM. 1990. Small-scale farmer-managed irrigation in Northern Nigeria. Geoforum, vol. 21, no. 4, pp. 435-443.

Knox J, Daccache A, Hess T. 2013. What is the impact of infrastructural investment on roads, electricity and agricultural productivity? DFID, United Kingdom.

Knox JW, Hess TM, Daccache A, Wheeler T. 2012. Climate change impacts on crop productivity in Africa and South Asia. Environmental Research Letters, vol. 7, no. 3. DOI: 10.1088/1748-9326/7/3/034032.

Kulecho IK, Weatherhead EK. 2006. Reasons for smallholder farmers discontinuing with low cost micro-irrigation: A case study from Kenya. Irrigation and Drainage, vol. 55, pp. 435444. DOI: 10.1007/s10795-005-4419-6.

Mangisoni JH. 2008. Impact of treadle pump irrigation technology on smallholder poverty and food security in Malawi: A case study of Blantyre and Mchinji districts. International Journal of Agricultural Sustainability, vol. 6, no. 4, pp. 248-266. DOI: 10.3763/ijas.2008.0306.

Matekere EC, Lema NM, 2012. Performance analysis of public funded irrigation projects in Tanzania. Irrigation \& Drainage Systems, 25(4), pp.237-253. DOI: 10.1007/s10795-0119119-9.

Mengistu A. 2008. Socio-economic assessment of two small-scale irrigation schemes in Adami Tullu Jido KombolchaWoreda, Central Rift Valley of Ethiopia. MSc thesis,Wageningen University. Wageningen, the Netherlands.

Namara RE, Hanjrab MA, Castilloc GE, Ravnborg HM, Smithe L, Van Koppen B. 2010. 
Agricultural water management and poverty linkages: Comprehensive Assessment of Water Management in Agriculture. Agricultural Water Management, vol. 97, no. 4, pp. 520-527.

Namara RE, Horowitz L, Kolavalli S, Kranjac-berisavljevic G, Dawuni BN, Barry B, Giordano M. 2010. Typology of irrigation systems in Ghana. International Water Management Institute (IWMI), Corombo, SriLanka.

Namara RE, Gebregziabher G, Giordano M, De Fraiture C. 2013. Small pumps and poor farmers in Sub-Saharan Africa: An assessment of current extent of use and poverty outreach. Water International, vol. 38, no. 6, pp. 827-839. DOI: 10.1080/02508060.2014.847777.

Namara RE, Hope, L, Sarpong EO, De Fraiture C, Owusu D. 2014. Adoption patterns and constraints pertaining to small-scale water lifting technologies in Ghana. Agricultural Water Management, vol. 131, pp. 194-203.

New Partnership for Africa's Development (NEPAD). 2003. Comprehensive Africa Agriculture Development Programme (CAADP), Midrand, South Africa

Njiraini GW, Guthiga PM. 2013. Are small-scale irrigators water use efficient: Evidence from Lake Naivasha Basin, Kenya. Environmental management, vol. 52, no. 5, pp. 1192-1201.

Sumberg J, Thompson J, Woodhouse P. 2012 Pathways to sustainability: Contested Agronomy; Agriculture research in a changing World, University of Sussex. Routledge, New York, USA.

Yakubov M. 2012. Assessing irrigation performance from the farmers' perspective: A qualitative Study. Irrigation and Drainage, vol. 61, no. 3, pp. 316-329.

You L, Ringler C, Wood-Sichra U, Robertson R, Wood S, Zhu T, Nelson G, Guo Z, Sun Y. 2011. What is the irrigation potential for Africa: A combined biophysical and socioeconomic approach. Food Policy, vol. 36, no. 6, pp. 770-782. DOI: 10.1016/j.foodpol.2011.09.001. 